\title{
CLIMATE VARIATIONS IN GREENHOUSE CULTIVATED WITH GERBERA AND RELATIONSHIP WITH EXTERNAL CONDITIONS
}

\author{
ADERSON S. DE ANDRADE JÚNIOR ${ }^{1}$, LISÂNEA M. O. DAMASCENO ${ }^{2}$, \\ NILDO DA S. DIAS ${ }^{3}$, HANS R. GHEYI ${ }^{4}$, CRISTIANE GUISELINI ${ }^{5}$
}

\begin{abstract}
Black meshes used in greenhouses provide shade to plants, affecting photosynthesis and presenting certain properties that change the microclimatic conditions in these environments. The objective of this study was to evaluate the variation in climate elements in greenhouse cultivated with gerbera (Gerbera jamesonii, Vr. Rambo) in relation to external conditions and the reference evapotranspiration (ETo) at Teresina, State of Piauí, Brazil. The measurements were obtained from July to October 2007 by an automatic data acquisition system installed inside and outside the greenhouse. The global solar radiation, evapotranspiration, precipitation, temperature, relative humidity, and wind speed were estimated. The results showed that major effect of the shading occurred on the mean air temperature during the 120 days, making it higher than the external environment. Inside the greenhouse, mean values of relative air humidity, reference evapotranspiração, global solar radiation and wind speed were lower compared to those outside the greenhouse.
\end{abstract}

KEYWORDS: meteorology, meteorological elements, floriculture, Gerbera jamesonii.

\section{VARIAÇÕES METEOROLÓGICAS EM AMBIENTE PROTEGIDO CULTIVADO COM GÉRBERAS E SUAS RELAÇÕES COM AS CONDIÇÕES EXTERNAS}

RESUMO: Os ambientes protegidos cobertos com malha negra fornecem sombreamento às plantas, têm forte influência no processo da fotossíntese e possuem propriedades particulares que interferem nas condições micrometeorológicas desses ambientes. Objetivou-se, neste trabalho, avaliar os elementos meteorológicos no interior do ambiente protegido cultivado com gérbera (Gerbera jamesonii, Vr. Rambo) em relação ao ambiente externo e na evapotranspiração de referência (ETo), a qual foi correlacionada às variáveis ambientais em Teresina-PI. No período de julho a outubro de 2007, os elementos meteorológicos foram obtidos por um sistema de aquisição de dados automático instalado no interior do ambiente protegido e externamente. Estimaram-se a radiação solar global, temperatura, umidade relativa do ar, evapotranspiração de referência, precipitação e velocidade do ar. Os resultados mostraram que o maior efeito da cobertura ocorreu sobre a temperatura média do ar durante os 120 dias, tornando-as acima das verificadas no ambiente exterior. Foram observados no ambiente protegido, valores médios de umidade relativa do ar, evapotranspiração de referência, radiação solar global e velocidade do vento, inferiores aos obtidos em condição de campo.

PALAVRAS-CHAVE: meteorologia, elementos meteorológicos, floricultura, Gerbera jamesonii.

\footnotetext{
${ }^{1}$ Eng ${ }^{\mathrm{o}}$ Agrônomo, Pesquisador da Embrapa Meio-Norte, Teresina - PI, aderson@ @pamn.embrapa.br.

${ }^{2}$ Tecnóloga em Meio Ambiente, Assessora da Superintendência de Licenciamento e Fiscalização Ambiental, Instituto do Meio Ambiente e dos Recursos Hídricos do Distrito Federal - IBRAM, Brasília - DF, lisaneadamasceno@ hotmail.com.

${ }^{3}$ Eng ${ }^{\circ}$ Agrônomo, Prof. Adjunto, Depto. de Ciências Ambientais e Tecnológicas, UFERSA, Mossoró - RN, nisdias @ gmail.com.

${ }^{4}$ Eng ${ }^{\mathrm{O}}$ Agrônomo, Prof. Visitante Nacional Sênior (CAPES), Núcleo de Engenharia de Água e Solo, UFRB, Cruz das Almas - BA, hans@pq.cnpq.br.

${ }^{5}$ Eng ${ }^{\circ}$ Agrônomo, Prof. Adjunto, Departamento de Tecnologia Rural, Área Construções Rurais e Ambiência, UFRPE, Recife - PE, cguiseli@hotmail.com.

Recebido pelo Conselho Editorial em: $1^{\circ}-2-2011$

Aprovado pelo Conselho Editorial em: 8-6-2011
} 


\section{INTRODUCTION}

The cultivation of flowers may be carried out in the open or in greenhouses covered with black meshes. Plants cultivated in the open field are susceptible to weather, especially heavy rainfall and sunlight. In greenhouse conditions, there generally is a significant increase in production and product quality, providing more guarantees of good yields to the farmer (GOMES et al., 2006; FERNANDES et al., 2006; BACKES et al., 2007).

Greenhouse cultivation of ornamental plants can be performed at different periods of the year, allowing producers to make better use of soil, optimize management and, above all, provide better market price (BOUERI \& LUNARDI, 2006).

Recent trends show that gerbera is in the top five cut flowers in the Dutch auctions (PAPADOPOULOS et al., 2004). No other flower has such a diversity of colors and shapes, which are fundamental factors of public attraction. So, chances are high for economic success, because specific technologies are used for each type of flower and climate adaptability of the cultivated species (GOMES et al., 2006).

In Brazil, cultivation of ornamentals is the activity that most invests in production technology of protected environments, due to the high demands of the consumer market and high economic value added to the products of this segment. This fact occurs because flower production is strongly influenced by regional climate factors. Thus, many researchers are engaged in studying the microclimate inside greenhouses, as well as the development of several crops subjected to this system for appropriate management (BEZERRA NETO et al., 2005; BOUERI \& LUNARDI, 2006; MEIRELLES et al., 2007).

When comparing crops under protected cultivation with those cultivated in the open, we find that evapotranspiration is generally lower in protected environments than in the field, basically due to the partial opacity to solar radiation of the plastic cover, and wind reduction, which are major factors of the evaporative demand of the atmosphere, although the temperature and relative air humidity, at times, can be respectively higher and lower in the protected environment than in the exterior, depending on the climate conditions (FARIAS et al., 1994).

Therefore, attention should be given to the climate demands of flowers grown under protected environment to allow achieving better productivity and high quality, since the environment exerts great influence on flower development. In cut flowers, air temperature influences the emission and growth of leaves, and early flowering, whereas soil temperature has a positive effect on head diameter and length of the flowering stem, and the relative humidity should be between 75 and $90 \%$ to avoid diseases (PANDORFI, 2006).

The most important climate element is solar radiation, which affects all other factors, such as air and soil temperature, atmospheric pressure, relative humidity and rainfall. Solar radiation is important because it acts decisively in all life processes of the plants, such as: photosynthesis, transpiration, photoperiod, tissue growth, flowering, etc (GUISELINI et al., 2010).

Temperature and light are primary factors of crop growth and development, but when these are too high, the development of leaves and shoots can be affected (SHIN et al., 2001), as observed in rose, with smaller size, fewer and smaller petals during flowering when high temperature was related with the number of cultivation days. SHIN et al. (2001) stated that the number of leaves per shoot of the rose was not affected by temperature, however, rod size, and the diameter and area of the leaf decreased as temperature increased.

Thus, in regions where solar radiation is high, it is recommended the use of meshes in protected environments to guarantee that the gerbera production is not affected by high temperatures, since these meshes provide shading to the plants and have properties that improve microclimatic conditions in this environment (AQUINO et al., 2007). It is desirable that the gerbera production occurs in a protected environment to achieve better productivity and quality of flowers, 
as well as it protects against rain, wind and reduces the attack of pests and diseases (GUISELINI et al., 2010).

Given all these, this work aimed to study the climate variations in greenhouse cultivated with gerbera (Gerbera jamesonii, variety Rambo) and its relations with the external environment in Teresina, PI, for proper management of this crop in the region.

\section{MATERIAL AND METHODS}

The study was conducted in greenhouse with $50 \%$ black mesh shade, $12 \mathrm{~m}$ wide, $19.5 \mathrm{~m}$ long and $2.5 \mathrm{~m}$ in height, totaling $234 \mathrm{~m}^{2}$ (Figure 1), located at Embrapa Meio-Norte, in the municipality of Teresina, PI, whose geographical coordinates are $05^{\circ} 05^{\prime} 21^{\prime}$ ' $\mathrm{S}$; $42^{\circ} 48^{\prime} 07^{\prime}$ ' $\mathrm{W}$ and $74 \mathrm{~m}$, in the period between July 2007 and January 2008.

According to the classification of Köeppen, the region of Teresina has hot tropical and humid climate with rains during summer and autumn and dry winter (type Aw). The average air temperature, maximum and minimum annual temperatures are $27.9 ; 33.8$ and $22.1^{\circ} \mathrm{C}$, respectively, with annual rainfall of $1,300 \mathrm{~mm}$, average wind speed of $1.6 \mathrm{~m} \mathrm{~s}^{-1}$, the average solar radiation of $7.7 \mathrm{~h}$ and daily average air humidity of $69.2 \%$ (BASTOS \& ANDRADE JÚNIOR, 2000), showing no typical definitions of seasons.

In the greenhouse, gerbera (Gerbera jamesonii, Vr. Rambo) was cultivated in plastic pots with a capacity of $5.0 \mathrm{~L}$, filled with soil. The soil used was sieved, air dried and placed in pots with perforated base, in on a $2 \mathrm{~cm}$ gravel layer, covered with a geotextile mat, thus resulting in a soil layer of $10 \mathrm{~cm}$, inside the protected environment. These pots were placed in suspended wooden benches $0.70 \mathrm{~m}$ high, $0.80 \mathrm{~m}$ wide and 6 feet long.

The soil used was originated from a profile classified as sandy Yellow Oxisol originated from Embrapa Meio-Norte, from which samples were withdrawn from the 0-15 cm layer for chemical analysis: $\mathrm{pH}=5.24$, phosphorus $=21,0 \mathrm{mg} \mathrm{dm}^{-3}, \mathrm{~K}=0.32 \mathrm{cmol}_{\mathrm{c}} \mathrm{dm}^{-3}$ and organic matter $=$ $16.68 \mathrm{~g} \mathrm{~kg}^{-1}$.

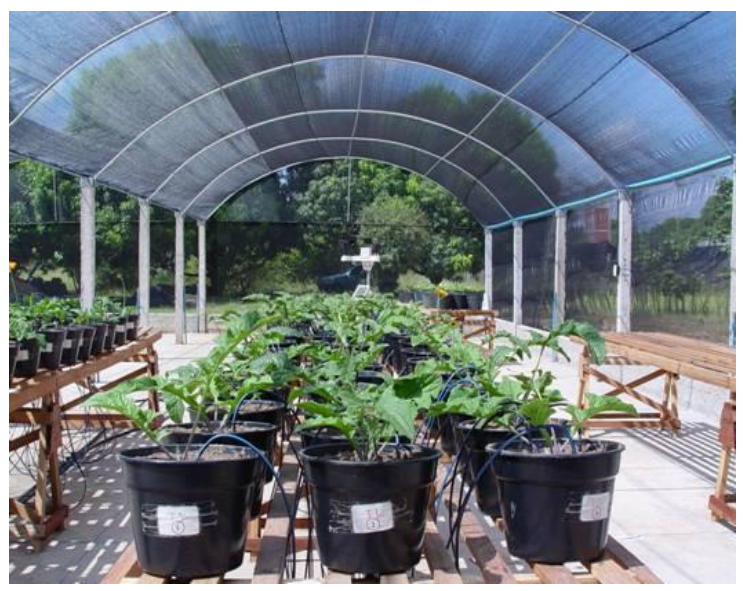

FIGURE 1. Details of shade mesh in greenhouse.

The water layer applied was calculated based on the reference evapotranspiration (ETo) from Penman-Monteith method (Eq. 1).

$$
\text { ETo }=\frac{0,408 \delta\left(\mathrm{R}_{\mathrm{n}}-\mathrm{G}\right)+\gamma 900 \mathrm{U}_{2}\left(\mathrm{e}_{\mathrm{S}}-\mathrm{e}_{\mathrm{a}}\right) /(\mathrm{T}+273)}{\delta+\gamma\left(1+0,34 \mathrm{U}_{2}\right)}
$$

where,

$$
\begin{aligned}
& \mathrm{R}_{\mathrm{n}} \text { - daily net radiation, } \mathrm{MJ} \mathrm{m}^{-2} \mathrm{~d}^{-1} ; \\
& \mathrm{G} \text { - soil heat flux, } \mathrm{MJ} \mathrm{m}^{-2} \mathrm{~d}^{-1} ; \\
& \gamma \text { - psychrometric constant }\left(0,063 \mathrm{kPa}^{\circ} \mathrm{C}^{-1}\right) ;
\end{aligned}
$$


$\mathrm{U}_{2}$ - wind speed at $2 \mathrm{~m}$ height, $\mathrm{m} \mathrm{s}^{-1}$;

$\mathrm{e}_{\mathrm{s}}$ - saturation vapor pressure, $\mathrm{kPa}$;

$\mathrm{e}_{\mathrm{a}}$ - partial vapor pressure, $\mathrm{kPa}$;

$\mathrm{T}$ - mean air temperature at $2 \mathrm{~m} \mathrm{high,}{ }^{\circ} \mathrm{C}$, and

$\delta$ - slope of the curve of water vapor saturation, $\mathrm{kPa}^{\circ} \mathrm{C}^{-1}$.

The climate variables were measured by an automatic weather station installed inside the protected environment with sensors located $1.50 \mathrm{~m}$ above the ground, next to the pots, to record global solar radiation (GSR), temperature (T) and relative humidity (RH). To measure RS, a LICOR pyranometer model LI-200X was used, T and RH were obtained by a psychrometer model HMP 35C (Campbell Sci Inc.) installed $1.5 \mathrm{~m}$ above the ground; Precipitation (P) was estimated by a rain gauge and ETo was calculated by Equation 1. Measurements were performed between 6 and $18 \mathrm{~h}$, at 15 -minute intervals. In the external environment, measurements were made by the weather station of Embrapa Meio-Norte, located 300 m away.

The inside and outside microclimates were monitored as well as their effects on the crop throughout the experiment. Data were recorded with a laptop on hourly, daily and monthly scales. The climate data inside the protected environment were correlated with external data. Regression analysis was carried out for quantitative data, relating climate elements with internal and external ETo inside the protected environment for the variables RH, T and GSR for both environments. In addition, ETo was estimated by means of multivariate analysis, using RH, T and GSR as independent variables in both environments.

\section{RESULTS AND DISCUSSION}

The observed difference in temperature between the internal and external environment was on average $1.9{ }^{\circ} \mathrm{C}$ in the initial months (July and August), $1.4{ }^{\circ} \mathrm{C}$ in September, reaching $2.3{ }^{\circ} \mathrm{C}$ in October (Table 1). The average air temperature inside the greenhouse was $8.5 \%$ higher than the external environment in the warmer months of the year, especially September and October. This difference between the environments was confirmed with the results obtained by SOUSA et al. (2002). BOUERI \& LUNARDI (2006) also observed temperatures on average $17 \%$ higher in the protected environment, i.e., $3.3{ }^{\circ} \mathrm{C}$ higher than outside.

TABLE 1 . Monthly mean climate data of temperature (T), relative humidity of air (UR), wind speed (WS), global solar radiation (GSR) and reference evapotranspiration (ETo) inside and outside the greenhouse during the experimental period.

\begin{tabular}{lcccccccccc}
\hline \multirow{2}{*}{ Period } & \multicolumn{2}{c}{$\mathrm{T}\left({ }^{\circ} \mathrm{C}\right)$} & \multicolumn{2}{c}{$\mathrm{UR}(\%)$} & \multicolumn{2}{c}{$\mathrm{WS}\left(\mathrm{m} \mathrm{s}^{-1}\right)$} & \multicolumn{3}{c}{$\mathrm{GSR}\left(\mathrm{MJ} \mathrm{m}^{-2}\right)$} & \multicolumn{2}{c}{$\mathrm{ET}_{0}(\mathrm{~mm})$} \\
\cline { 2 - 10 } & \multicolumn{2}{c}{ Internal External Internal External } & Internal External & Internal & External & Internal & External \\
\hline July & 28.8 & 26.9 & 35.4 & 67.6 & 0.02 & 1.08 & 266.2 & 650.4 & 62.9 & 130.5 \\
August & 28.9 & 27.0 & 26.0 & 58.1 & 0.06 & 1.41 & 294.8 & 733.9 & 71.5 & 160.4 \\
September & 30.6 & 29.2 & 20.6 & 51.6 & 0.07 & 1.02 & 300.5 & 673.6 & 76.2 & 161.4 \\
October & 31.7 & 29.4 & 21.3 & 54.0 & 0.06 & 1.03 & 322.7 & 702.3 & 97.0 & 162.1 \\
\hline
\end{tabular}

Figure 2A shows the average daily temperature values inside (IT) and outside (ET) of protected environment and Figure $2 \mathrm{~B}$ shows a regression analysis. There is a linear effect between IT and ET ( IT $=0.8758 \mathrm{ET}+5.1604$ and $\mathrm{R}^{2}=0.97$ ), with average increase of $1.64{ }^{\circ} \mathrm{C}$ in the average temperature inside the greenhouse, which was expected due to the decreased convective process provided by the coverage of a protected environment, which prevents the passage of hot air to the outside. The lower volume of air to be heated as compared to the external environment should also be considered.

Figure 3 shows the variations in temperature and relative humidity in the time scale at the end of each month, selected to exemplify that the only stress was in the protected environment during 
the test. In these months, the air temperature reached peaks of $40{ }^{\circ} \mathrm{C}$ and lower critical values of relative humidity (10 to $20 \%$ ). The variation of the relative humidity was inversely proportional to air temperature, which indicates variations in these values with differences between the environments studied.

A.

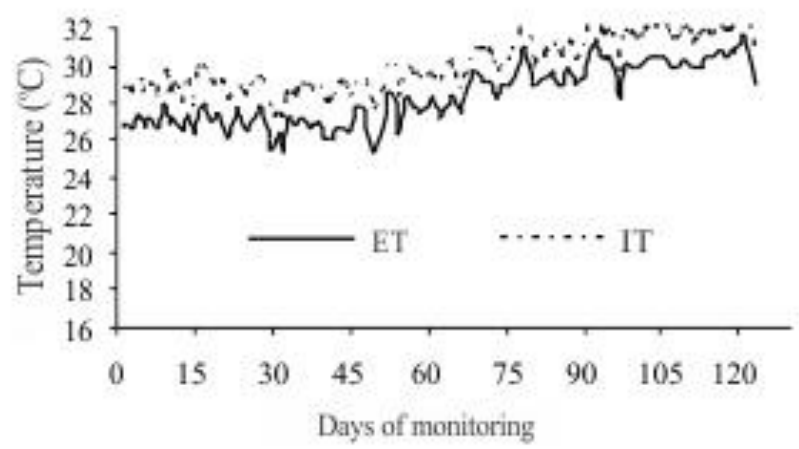

B.

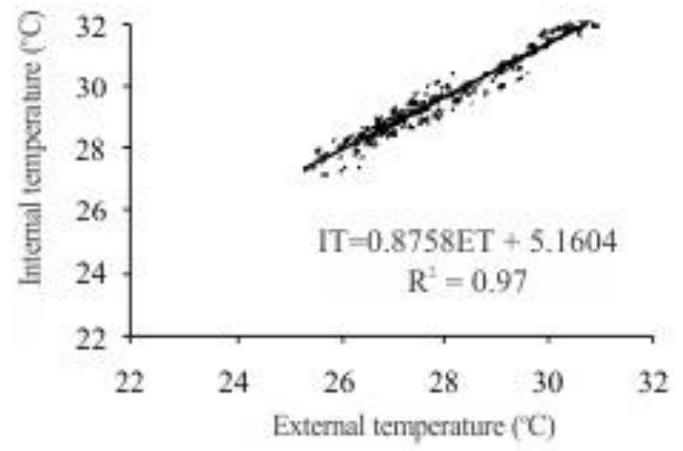

FIGURE 2. Daily mean temperature of air inside (IT) and outside (ET) the greenhouse (A) and regression analysis $(\mathrm{B})$.

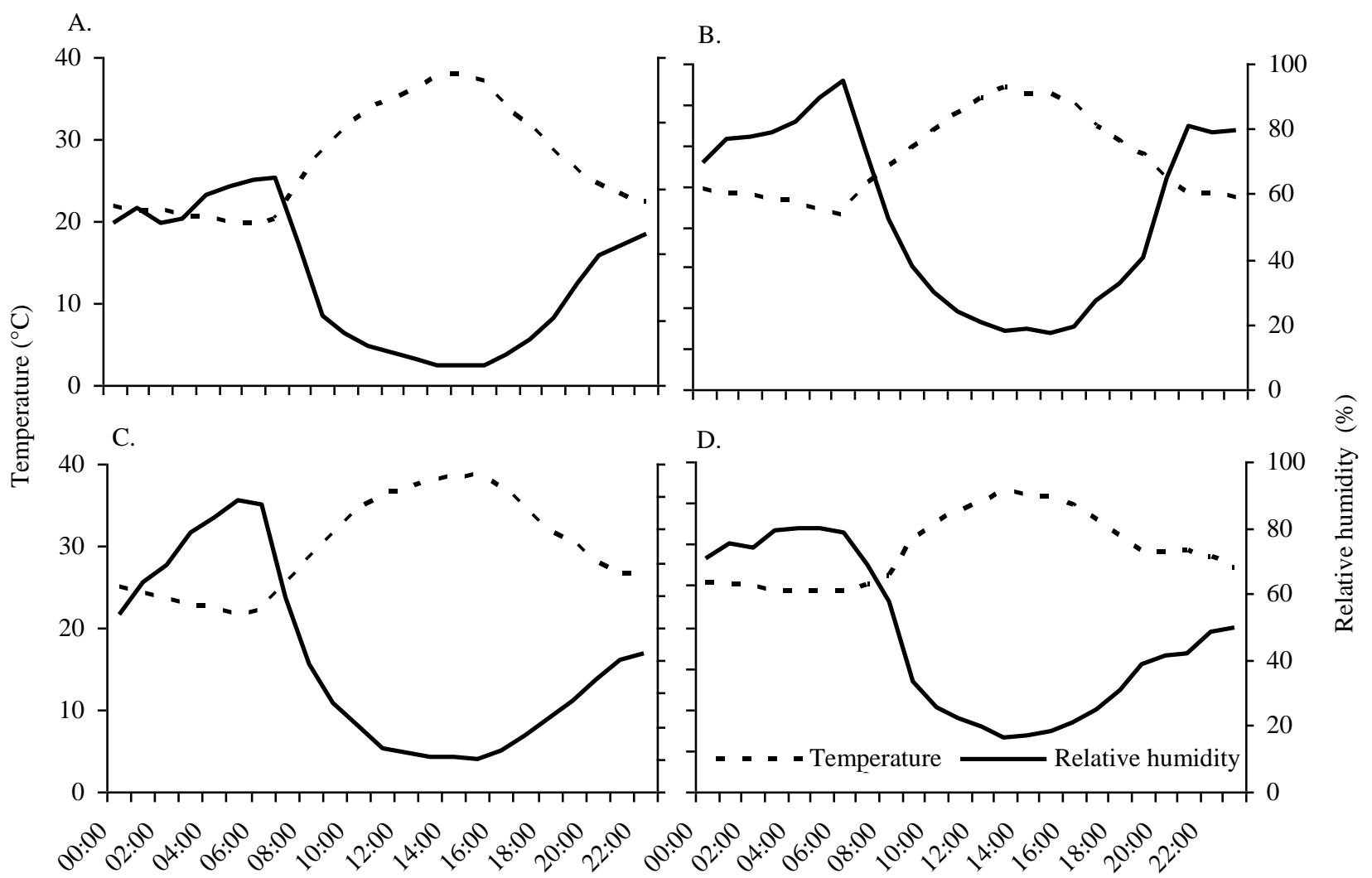

FIGURE 3. Hourly variation of air temperature versus relative air humidity recorded inside the greenhouse on $30^{\text {th }}$ of July (A), August (B), September (C) and October (D).

Table 1 shows the maximum monthly relative humidity for the greenhouse and external conditions. There was a trend lower values were observed under the protected condition, inversely proportional to air temperature, which was higher. The relative humidity inside the greenhouse was lower than the outside in about 3.2\% over this period. According to BOUERI \& LUNARDI (2006), the humidity variation inside the protected environment depends mainly on air temperature and 
ventilation. The authors observed for carnation cultivated in a protected environment that the relative humidity corresponded to $93 \%$ of relative humidity observed in the field. Similar results were also obtained by GUISELINI et al. (2007), PANDORFI (2006) and SOUSA et al. (2002).

It can also be seen in Table 1 that in the period between July and October, there was a reduction in the average air humidity, the variation in the internal environment was 35 to $21 \%$, while the external was 68 to $54 \%$. This occurred because of the regional climate that tends to raise the temperature, especially in September and October, in which there is a lower frequency of rainfall, causing a decrease in the values of relative humidity in the region. Data of relative humidity recorded during the study were lower than those indicated for gerbera cultivation. The air humidity range considered optimal for this crop ranges from 75 to 90\% (PANDORFI, 2006).

Solar radiation incident in the course of the experiment showed a difference between the external and internal environments of $384.2 ; 439.1 ; 373.1$ and $379.6 \mathrm{MJ} \mathrm{m}^{-2}$, respectively, for the months of July, August, September and October (Table 1).

Daily average values of global solar radiation (GSR) measured inside and outside the protected environment during the experiment, and the regression analysis are presented in Figure 4. Integrated values of Internal Global Solar Radiation (I-GSR) amounted to $1184.24 \mathrm{MJ} \mathrm{m}^{-2}$ with an average of $9.63 \mathrm{MJ} \mathrm{m}^{-2}$ day $^{-1}$, while the External Global Solar Radiation (E-GSR) was 2760.20 $\mathrm{MJ} \mathrm{m}^{-2}$ with an average of $22.44 \mathrm{MJ} \mathrm{m}^{-2}$ day $^{-1}$ (Table 1). There is the linear relation between I-GSR and E-GSR $\left(\mathrm{R}^{2}=0.64\right)$, with monthly E-GSR values on average 2.33 times higher than I-GSR, due to the reflection and absorption of the plastic cover material in the protected environment, resulting in a decrease of global solar radiation inside the greenhouse.

There was no significant rainfall during the experiment, except at the end (October). Nevertheless, the high air temperature contributed to promote the low relative humidity in the internal environment, while remaining similar to the external environment. The low incidence of wind during the period did not favor thermal exchanges and removal of water vapor inside the greenhouse, with this situation becoming more pronounced due to the intense solar radiation of the period.

A.

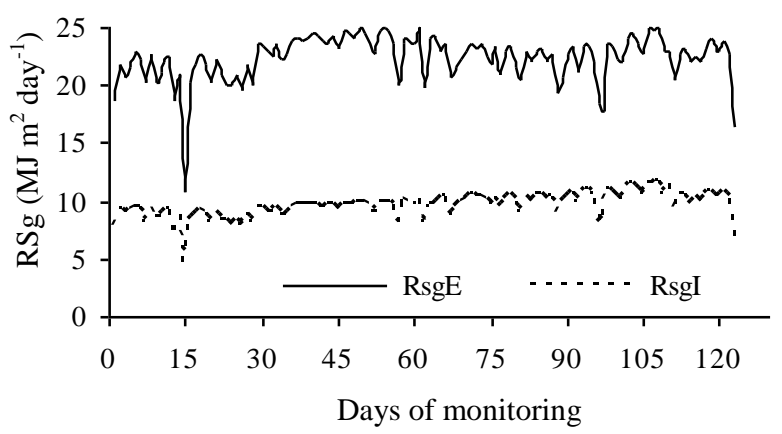

B.

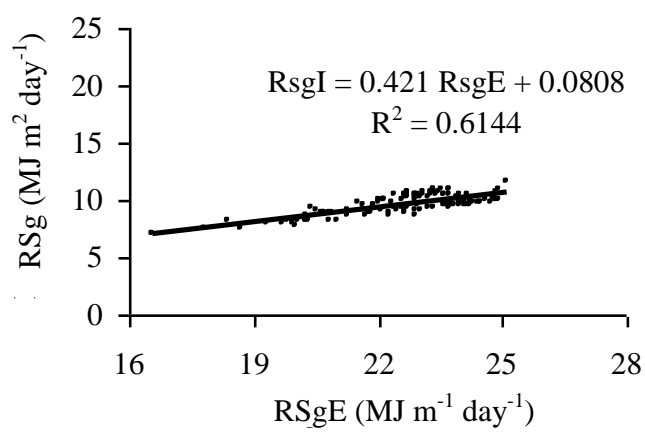

FIGURE 4. Daily global solar radiation inside and outside the greenhouse (A) and regression analysis between RsgI (I-GSR) and RsgE (E-GSR) (B).

Problems related to wind inside the protected environments are nearly always associated to low speed in relation to the external environment (GUISELINI et al. 2007), because wind is responsible for increasing air renewal around the leaf, which elevates aerodynamic conductance and results in higher plant transpiration values (LARANJEIRA, 2005). BOUERI \& LUNARDI (2006) observed that daily averages of wind speed at $2 \mathrm{~m}$ height in protected environment with carnation was $0.41 \mathrm{~m} \mathrm{~s}^{-1}$ where averages of $1.67 \mathrm{~m} \mathrm{~s}^{-1}$ were found in the field, confirming the protective effect. According to FARIAS et al. (1994), wind speed inside the greenhouse is estimated as approximately $5 \%$ of the value verified externally. This may constitute an advantage as it improves 
the efficiency of defensives while decreasing losses due to risk of mechanical damage in the plants and avoiding the spread of fungi spores and other pathogens.

Solar radiation values $\left(>300 \mathrm{MJ} \mathrm{m}^{-2}\right)$, high daytime temperatures $\left(>30^{\circ} \mathrm{C}\right)$ and low humidity $(<50 \%)$ can lead to situations of heat and water stress for species grown in a protected environment, limiting significantly plant transpiration and therefore, crop productivity. According to BECKMANN et al. (2006), crop growth and development depend on the intensity, quality and duration of sunlight, being these factors of vital importance to the plants. The availability of solar radiation inside protected environments is reduced compared to the external environment, due to reflection and absorption by the cover material. The differences in the reception of solar radiation in internal environments reflected on the crop performance regarding phenological and productive traits. The I-GSR was on average $42 \%$ that of E-GSR; VASQUEZ et al. (2005) in turn estimated I-GSR as $70 \%$ of the E-GSR.

With respect to the monthly reference evapotranspiration $\left(\mathrm{ET}_{0}\right)$, it was observed that the internal environment ranged from 62 to $97 \mathrm{~mm}$, while the external environment was between 130 and $162 \mathrm{~mm}$ during the same period (Table 1). The internal $\mathrm{ET}_{0}$ remained always lower than the external $\mathrm{ET}_{0}$ in about 45 to $77 \%$ (Figure $5 \mathrm{~A}$ ), and during the period it was on average $55.3 \%$ of the external $\mathrm{ET}_{0}$, which explains $60 \%$ of the variation of the internal $\mathrm{ET}_{0}$ (Figure $5 \mathrm{~B}$ ). This difference is related to microclimate changes caused by the use of a protected environment, as reported by DALMAGO et al. (2006), REIS et al. (2009) and GUISELINI et al. (2010), causing water consumption of crops in protected environments to be lower than in field conditions. PIVETTA et al. (2010) attribute this change mainly to the partial opacity of the cover, solar radiation and the wind reduction, which are major factors of the atmospheric evaporative demand.

The external and internal elements of the climate were related to the reference evapotranspiration $\left(\mathrm{ET}_{0}\right)$ inside the protected environment, as shown in Figure 6. For the climate internal elements, the best adjustment was obtained considering the internal global solar radiation, followed by relative humidity and temperature, with $\mathrm{R}^{2}$ of $0.7298,0.6217$ and 0.614 , respectively (Figure 6). As for the external elements, only global solar radiation showed no significant correlation with I-ET ${ }_{0}$. In Piracicaba, São Paulo State, VÁSQUEZ et al. (2005) found no significant correlation between the average values of ET and $\mathrm{ET}_{0}$ inside the protected environment, but the authors say it is likely that the leaf temperature had better correlation because the readings were carried out "in situ" (micro-scale).

A

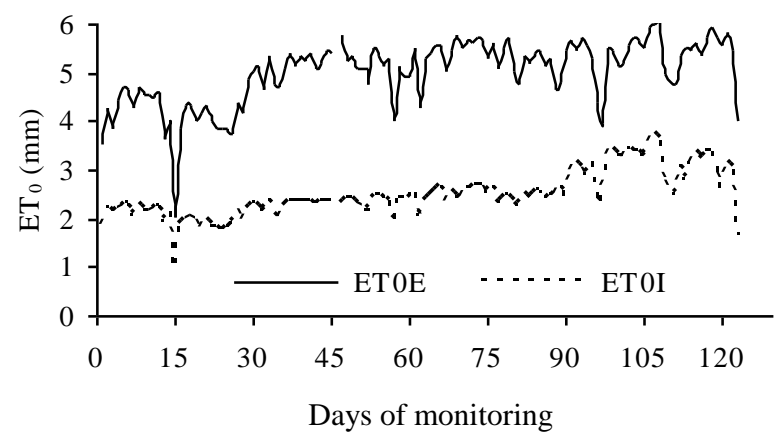

B.

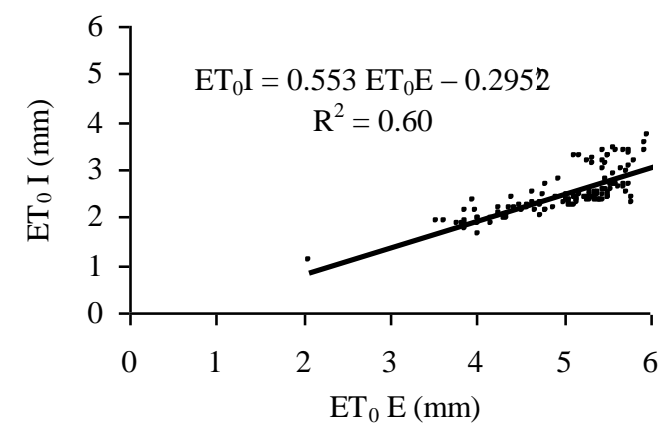

FIGURE 5. Daily reference evapotranspiration inside and outside of greenhouse (A) and regression analysis between $\mathrm{ET}_{0} \mathrm{I}\left(\mathrm{I}-\mathrm{ET}_{0}\right)$ and $\mathrm{ET}_{0} \mathrm{E}\left(\mathrm{E}-\mathrm{ET}_{0}\right)(\mathrm{B})$.

It is well accepted that protected environments produce microclimate changes in relation to the external environment, due to a reduction in the incidence of solar radiation on plants and the 
conditions of temperature, relative humidity and wind speed, which are determinants of evapotranspiration ( PEZZOPANE et al., 2000; GOMES et al., 2006).
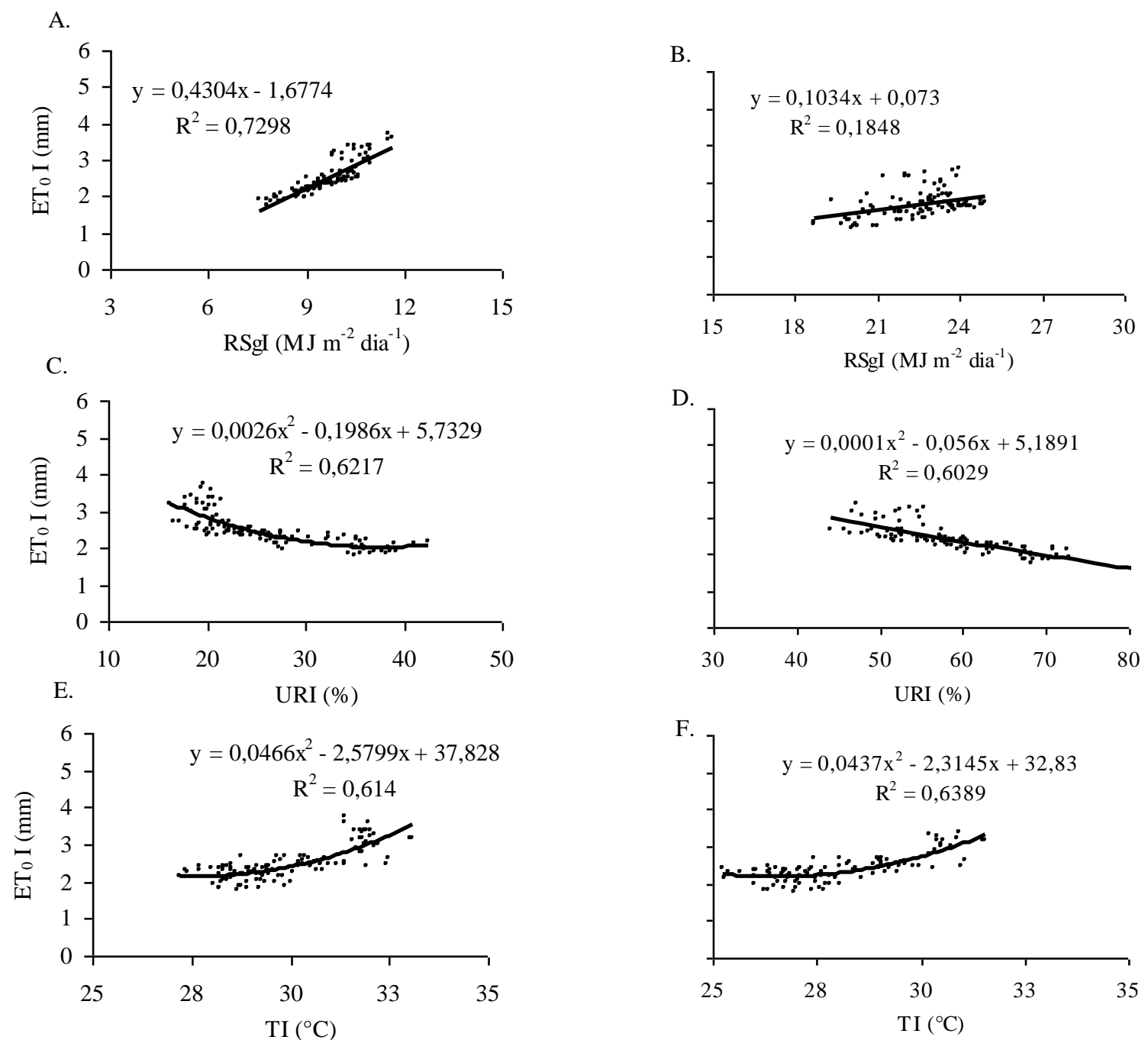

FIGURE 6. Relationship between daily reference evapotranspiration in internal environment and the internal Global Solar Radiation (RsgI) (A), external Global Solar Radiation (RsgE) (B), internal relative humidity (URI) (C), external relative humidity (URE) (D), internal temperature (TI) (E) and external temperature(TE) (F).

Table 2 presents multivariate regression models to estimate reference evapotranspiration internal (I-ET $)_{0}$ according to external and internal climate elements in the protected environment. For independent variables inside the protected environment, it was verified that $\mathrm{I}_{-} \mathrm{ET}_{0}$ could be estimated more accurately $\left(\mathrm{R}^{2}=0.801\right)$ with inclusion of the three independent variables studied (IT, UR and I-GSR). Conversely, I-ET 0 can also be estimated with a single dependent variable, e.g. the internal or external temperature in the protected environment as indicated in Figure 6C; however with less accuracy than the multivariate analysis $\left(R^{2}=0.614\right.$ and 0.6389 for ET and IT, respectively), which is a climate element easily estimated by farmer; it is noteworthy to mention that though these correlation coefficients are lower than relationship I-ET $\mathrm{E}_{0}$ and $\mathrm{E}_{-} \mathrm{ET}_{0}\left(\mathrm{R}^{2}=0.60\right)$. In the literature, the relationship between evapotranspiration with solar radiation and the temperature has been referred as the best alternative to estimate water requirement of crop under protected environment (BONACHELLA et al. 2006), which in this case explains $79.4 \%$ of the variation, value very close to the obtained in present study when using three variables $(80.1 \%)$.

Still in Table 2, it can be seen that ETo in the greenhouse may be estimated though with less accuracy with inclusion of external climate elements as dependent variables in the multivariate analysis. 
TABLE 2. Models of multivariate regression to estimate internal reference evapotranspiration using internal and external climate elements of the greenhouse.

\begin{tabular}{|c|c|c|}
\hline \multirow{2}{*}{ Variables } & Equation & \multirow{2}{*}{$\mathrm{R}^{2}$} \\
\hline & Internal climate elements & \\
\hline$\overline{\mathrm{I} \mathrm{ET}_{0}(\mathrm{IT}, \mathrm{I}-\mathrm{UR})}$ & $\mathrm{ET}_{0}=-0.977+0.141 \mathrm{IT}-0.029 \mathrm{I}-\mathrm{UR}$ & $0.682 * *$ \\
\hline $\mathrm{I}^{-E_{0}}(\mathrm{IT}, \mathrm{I}-\mathrm{GSR})$ & $\mathrm{ET}_{0}=-3.671+0.103 \mathrm{IT}+0.318 \mathrm{I}-\mathrm{GSR}$ & $0.794 * *$ \\
\hline $\mathrm{I}^{-E T_{0}}(\mathrm{I}-\mathrm{UR}, \mathrm{I}-\mathrm{GSR})$ & $\mathrm{ET}_{0}=-0.3669-0.016 \mathrm{I}-\mathrm{UR}+0.338 \mathrm{I}-\mathrm{GSR}$ & $0.756 * *$ \\
\hline${\mathrm{I}-\mathrm{ET}_{0}(\mathrm{IT}, \mathrm{I}-\mathrm{UR}, \mathrm{I}-\mathrm{GSR})}$ & $\mathrm{ET}_{0}=-2.731+0.091 \mathrm{IT}-0.009 \mathrm{I}-\mathrm{UR}+0.28 \mathrm{I}-\mathrm{GSR}$ & $0.801 * *$ \\
\hline \multicolumn{3}{|c|}{ External climate elements } \\
\hline $\mathrm{E}^{-\mathrm{ET}_{0}}(\mathrm{ET}, \mathrm{E}-\mathrm{UR})$ & $\mathrm{ET}_{0}=1.327+0.092 \mathrm{ET}-0.026 \mathrm{E}-\mathrm{UR}$ & $0.698 * *$ \\
\hline 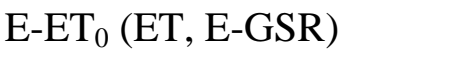 & $\mathrm{ET}_{0}=-4.701+0.168 \mathrm{ET}+0.105 \mathrm{E}-\mathrm{GSR}$ & $0.740 * *$ \\
\hline $\mathrm{E} \mathrm{ET}_{0}(\mathrm{E}-\mathrm{UR}, \mathrm{E}-\mathrm{GSR})$ & $\mathrm{ET}_{0}=4.069-0.037 \mathrm{E}-\mathrm{UR}+0.022 \mathrm{E}-\mathrm{GSR}$ & $0.609 * *$ \\
\hline $\mathrm{E} \mathrm{ET}_{0}(\mathrm{ET}, \mathrm{E}-\mathrm{UR}, \mathrm{E}-\mathrm{GSR})$ & $\mathrm{ET}_{0}=-2.269+0.131 \mathrm{ET}-0.013 \mathrm{E}-\mathrm{UR}+0.077 \mathrm{E}-\mathrm{GSR}$ & $0.763 * *$ \\
\hline
\end{tabular}

\section{CONCLUSIONS}

The climate parameters humidity, wind speed and evapotranspiration in the greenhouse were on average lower than the external conditions, while temperature was higher.

$\mathrm{ET}_{0}$ inside the protected environment can be estimated with acceptable accuracy to manage the crop irrigation by means of mathematical models that include variables such as UR, GSR and T estimated in the inside and outside environment of the greenhouse.

\section{ACKNOWLEDGEMENTS}

To CNPq for the fellowship, and the Fundação de Amparo à Pesquisa do Piauí (FAPEPI) for funding this research project.

\section{REFERENCES}

AQUINO, L.A.; PUIATTI, M.; ABAURRE, M.E.O. Produção de biomassa, acúmulo de nitrato, teores e exportação de macronutrientes da alface sob sombreamento. Horticultura Brasileira, Brasília, v.25, n.3, p.381-386, 2007.

BACKES, F.A.A.L.; BARBOSA, J.C.; CACON, P.R.; GROSSI, J.A.S.; BACKERS, R.L.; FINGER, F.L. Cultivo hidropônico de lisianto para flor de corte em sistema de fluxo laminar de nutrientes. Pesquisa Agropecuária Brasileira, Brasília, v.42, n.11, p.1.561-1.566, 2007.

BASTOS, E.A.; ANDRADE JUNIOR, A.S. de. Dados agrometeorologicos para o município de Teresina, PI (1980-1999). Teresina: Embrapa Meio-Norte, 2000. 25 p. (Embrapa Meio-Norte. Documentos, 47)

BECKMANN, M.Z.; DUARTE, G.R.B.; PAULA, V.A. de; MENDEZ, M. E.G.; PEIL, R.M.N. Radiação solar em ambiente protegido cultivado com tomateiro nas estações verão-outono do Rio Grande do Sul. Ciência Rural, Santa Maria, v.36, n.1, p.86-92, 2006.

BEZERRA NETO, F.; ROCHA, R.C.C.; NEGREIROS, M.Z.; ROCHA, R.H.C.; QUEIROGA, R.C.F. Produtividade de alface em função de condições de sombreamento e temperatura e luminosidade elevadas. Horticultura Brasileira, Brasília, v.23, n.2, p.189-192, 2005.

BONACHELLA, S.; GONZALEZ, M.A.; FERNANDÉZ, M.D. Irrigation scheduling of plastic greenhouse vegetable crops based on historical weather data. Irrigation Science, New York, v.25, n.1, p.25-62, 2006. 
BOUERI, M.A.; LUNARDI, D.M.C. Avaliação de elementos agrometeorólogicos no cultivo do cravo-de-defunto (Tagetes sp.) em ambiente protegido e a campo. Revista Energia na Agricultura, Botucatu, v.21, n.3, p.45-54, 2006.

DALMAGO, G.A.; HELDWEIN, A.B.; NIED, A.H.; GRIMM, E.L.; PIVETTA, C.R. Evapotranspiração máxima da cultura de pimentão em estufa plástica em função da radiação solar, da temperatura, da umidade relativa e do déficit de saturação do ar. Ciência Rural, Santa Maria, v.36, n.3, p.785-792, 2006.

FARIAS, J.R.; BERGAMASCHI, H.; MARTINS, S.R. Evapotranspiração no interior de estufas plásticas. Revista Brasileira de Agrometeorologia, Santa Maria, v.2, n.1, p.17-22, 1994.

FERNANDES, A.L.T.; FOLEGATTI, M.V.; PEREIRA, A.R. Avaliação de diferentes métodos de estimativa da evapotranspiração da cultura do crisântemo (Chrisantemum spp.) cultivado em estufa plástica. Irriga, Botucatu, v.11, n.2, p.139-149, 2006.

GOMES, A.R.M.; D’ÁVILA, J.N.T.; GORDIM, R.S.; BEZERRA, F.C.; BEZERRA, F.M.L. Estimativa da evapotranspiração e coeficiente de cultivo da Heliconia psittacorum L x H. spathocircinada (Arist) cultivada em ambiente protegido. Revista Ciência Agronômica, Fortaleza, v.37, n.1, p.13-18, 2006.

GUISELINI, C.; SENTELHAS, P.C.; PANDORFI, H.; HOLCMAN, E. Manejo da cobertura de ambientes protegidos: radiação solar e seus efeitos na produção da gérbera. Revista Brasileira de Engenharia Agrícola e Ambiental, Campina Grande, v.14, n.6, p.645-652, 2010.

GUISELINI, C.; SENTELHAS, P.C.; PANDORFI, H.; HOLCMAN, E. Temperatura e umidade do ar em ambientes protegidos cobertos com plástico transparente associado à malha termorefletora, instalada externa e internamente. Revista Brasileira de Agrometeorologia, Santa Maria, v.15, n.1, p.157-162, 2007.

LARANJEIRA, E.G. Modelo computacional para supervisão e controle de casas de vegetação. 2005. 105 f. Dissertação (Mestrado e Agronomia) - Universidade Estadual de Campinas, Campinas, 2005.

MEIRELLES, A.J.A.; PAIVA, P. D. de O.; OLIVEIRA, M. I. de: TAVARES, T.S. Influência de diferentes sombreamentos e nutrição foliar no desenvolvimento de mudas de palmeira Ráfia Rhapis excelsa (THUNBERG) Henry Ex. Rehder. Ciência e Agrotecnologia, Lavras, v.31, n.6, p.18841887, 2007.

PAPADOPOULOS, I.; CHIMONIDOU, D.; SAVIDES, S; POLYCARPO, P. Optimization of irrigation with treated wastewater on flower cultivations. In: WORKSHOP NON-

CONVENTIONAL WATER USE, 2004, Cairo. Disponível em:

<http://wasamed.iamb.it/allegati_int/18/.cyprus1.pdf>. Acesso em: 2 fev. 2004.

PANDORFI, C.G. Microclima na produção de gérbera em ambiente protegido com diferentes tipos de cobertura. 2006. 96 f. Tese (Doutorado em Física da Ambiente Agrícola) - Escola Superior de Agricultura 'Luiz de Queiroz', Universidade de São Paulo, Piracicaba, 2006.

PEZZOPANE, J.E.M.; OLIVEIRA, P.C. de; REIS, E.F. dos. Alterações microclimáticas causadas pelo uso de tela plástica. Revista Brasileira de Agrometeorologia, Santa Maria, v.8, n.1, p.11-18, 2000.

PIVETTA, C.R.; HELDWEIN, A.B.; MALDANER, I.C.; RADONS, S.Z.; TAZZO, I.F.; LUCAS, D.D. Evapotranspiração máxima do pimentão cultivado em estufa plástica em função de variáveis fenométricas e meteorológicas. Revista Brasileira de Engenharia Agrícola e Ambiental, v.14, n.7, p.768-775, 2010.

REIS, L.S.; SOUZA, J.L.; AZEVEDO, C.A.V. Evapotranspiração e coeficiente de cultivo do tomate caqui cultivado em ambiente protegido. Revista Brasileira de Engenharia Agrícola e Ambiental, Campina Grande, v.13, n.3, p.289-296, 2009. 
SHIN, H.K.; LIETH, J.H.; KIM, SOO-HYUNG. Effects of temperature on leaf area and flower size in rose. Rose Research. Acta Horticulturae, Alexandria, v.1, n.547, p.185-191, 2001.

SOUSA, J.W.; MARTINS, D.; CUNHA, A.R.; ESCOBEDO, J.F.; GALVANI, E. Alterações da temperatura e umidade relativa do ar em ambiente protegido com cobertura de polietileno difusor de luz. Revista Brasileira de Agrometeorologia, Santa Maria, v.10, p.1-9, 2002.

VASQUEZ, M.A.N.; FOLEGATTI, M.V.; DIAS, N.S.; SILVA, C.R. da. Efeitos do ambiente protegido cultivado com melão sobre os elementos meteorológicos e sua relação com as condições externas. Engenharia Agrícola, Jaboticabal, v.25, n.1, p.137-143, 2005. 